\title{
Article
}

\section{Benefits of Quality Management Standards in Organizations}

\author{
Arūnas Zgirskas (ㅁ), Juozas Ruževičius * and Darius Ruželè \\ Department of Management, Faculty of Economics and Business Administration, Vilnius University, \\ LT-10222 Vilnius, Lithuania; arunas.zgirskas@gmail.com (A.Z.); darius.ruzele@evaf.vu.lt (D.R.) \\ * Correspondence: juozas.ruzevicius@evaf.vu.lt
}

check for updates

Citation: Zgirskas, A.; Ruževičius, J.;

Ruželè, D. Benefits of Quality

Management Standards in

Organizations. Standards 2021, 1 ,

154-166. https://doi.org/10.3390/

standards1020013

Academic Editor:

Evangelos Grigoroudis

Received: 27 August 2021

Accepted: 30 September 2021

Published: 6 December 2021

Publisher's Note: MDPI stays neutral with regard to jurisdictional claims in published maps and institutional affiliations.

\begin{abstract}
The main motives for implementing standards are external and internal. External motives are related with aims to enter new markets, export new goods, meet customer requirements, achieve better corporate image, gain market share, or increase customer satisfaction. Internal motives occur when the organization itself wants to improve the internal system and when processes and benefits depend on the internal motives of the organization. In order to disclose the benefits of quality standards, an empirical study was conducted with quality representatives from organizations in different fields of business activity in Lithuania. The research aimed to investigate what quality management systems prevail in organizations and to reveal the motives and benefits of implementation. The empirical study found that after the implementation of quality management standards (QMS), the quality level improved; the number of incidents and defects (complaints) decreased; employee involvement and perception of quality increased; company profits increased; customer satisfaction increased; and company management was improved.
\end{abstract}

Keywords: standards; quality management; implementation motives; benefits of standards implementation

\section{Introduction}

Standards play an important role in a globalizing world, both in terms of quality of life and in economic terms; however, the implementation of standards in organizations remains a delicate topic. There are still no full answers to questions regarding products, provision of services, how an organization is affected by quality systems, how standards can benefit an organization, and what added value is created by complying with standards. Consequently, the aim of the research was to reveal what kind of motives and benefits create the implementation of quality management standards for organizations today and to evaluate if there are any changes compared to previous research studies.

The research proved that the list of main motives and benefits for implementing quality management standards in organizations remains the same as it was revealed by previous studies: motives remain as a demand/pressure from the customers, while organizations want to increase market share or improve the quality of their product/services. Benefits in organizations are reflected by a decreased number of incidents, improved profitability, processes, procedures, etc.

The research also identified motives not mentioned in previous studies: (a) organizations could not operate their business without relevant standards or (b) organizations aimed to increase operational efficiency. New benefits appeared through managementafter the QMS implementation, it became easier to manage organization, and operational efficiency increased.

\section{Literature Review}

The main motives and benefits of implementing quality management standards are external and internal [1]. External motives arise organically, when organizations aim to enter new markets, export new goods, meet customer requirements, achieve a 
better image, gain a larger share of the market, or increase customer satisfaction. Internal implementation motives occur when the organization itself wants to improve its internal system and processes [2]. Received benefits depend on the organization, and if standards are implemented solely based on external motives, there may be no significant benefits at all. Benefits are far greater when quality standards are implemented to increase the efficiency of the structure, systems, and processes of the organization [3].

Internal motives, which are factors that drive companies to adopt a certification approach, are related to anticipation and efficiency, which concern the reason for improving the company's image, internal processes, functional areas, maintaining the competitive position in time of economic crisis as well as the improvement of quality as part of the strategy of these companies [4].

Some organizations implement quality management systems based on external motives, when aiming to enter new markets, meet product export requirements, or meet customer requirements. Organizations also implement quality management systems because of the desire to gain a competitive advantage or as a response to future customers' satisfaction. Additionally, organizations use certification in the marketing of the company in order to increase its customer portfolio [4].

Both Ruževičius [5] and Gotzamani [6] distinguish internal-motive (MI) and externalmotive (ME) quality management system implementation, and internal-benefit (BI) and external-benefit (BE) quality management system implementation, as presented in Table 1 below.

Table 1. Internal and external quality management system implementation motives (developed by authors based on $[1,3,5]$ ).

\begin{tabular}{ccc}
\hline Motives & Type & Benefits \\
\hline Decision of the highest authority & MI & Improved quality of products and/or services \\
\hline Improvement of quality of products and/or services & MI & Decreased number of incidents, rejections, and complaints \\
\hline Improvement of processes and procedures & BI & Increased productivity and/or efficiency \\
\hline Reduction in incidents, rejections, and complaints & MI & Decreased internal costs \\
\hline Used as a basis for reducing internal costs & MI & Improved profitability \\
\hline Improvement of communication in the organization & MI & Increased workforce motivation and retention \\
\hline Improvement of management-employee relations & MI & Employees have a better understanding of quality \\
\hline Used as a promotional and/or marketing tool & ME & Improved processes and procedures \\
\hline Maintaining and/or increasing the market share & ME & Elimination of excess work \\
\hline Demand and/or pressure of customers & ME & Better working environment \\
\hline Competitive advantage & ME & Better customer service \\
\hline Condition to compete in the sector & ME & BI \\
\hline Our competitors who have implemented ISO 9000 standards & ME & Expansion into international markets \\
\hline Direct way to a new market & ME & Greater competitive advantage \\
\hline To be a good example for suppliers & ME & Effective promotional and/or marketing tool \\
\hline Improvement of public image of the organization & ME & BI \\
\hline At the request of the Government & ME & Established and/or improved mutual cooperation with suppliers \\
\hline BE & BI & BE \\
\hline
\end{tabular}

The type of motivation for implementing quality management systems affects the performance of the system. Organizations that focus on real quality improvements and organizational needs achieve higher benefits from their QMS implementation in areas like quality and operational improvement, compared to those organizations that implement and seek certification of their QMS for external motives, for example, image or customer requirements. Thus, a QMS implemented based upon external requirements tends to focus more on compliance and control and less on organizational efficiency [7]. 
According to Gotzamani [6], another important part regarding the effectiveness of standards is related to their ability to actually improve quality (internal and external) and customer satisfaction. The question mainly arises due to the fact that the standards do not require any evidence of the overall success and benefits of quality assurance systems in certified companies. A company may well be certified according to ISO 9001 standard without having to prove the existence of operational, economical, or other customer-related benefits that it has achieved through its implementation [6], or certain organizations are involved in the implementation of the ISO 9001 standard for marketing purposes only, without actually aiming to improve their quality management [2].

At the same time, evidence suggests that quality management systems provide a critical and established structure with the potential to create value, contribute to product quality and operational performance, increase net asset value, and support continuous improvement [7].

Others claim that the major benefits of purchasing from ISO 9001-certified companies include better, assured, and consistent product and service quality with prompt and speedy supply (shorter delivery lead times); in this way, there are fewer complaints and a better image for the company. Improved response to customer complaints is seen as the most significant positive change in performance demonstrated by certified companies [8].

\section{Materials and Methods}

\subsection{Research Aim and Methodology}

The research aimed to determine which quality management standards are used in Lithuanian organizations that are operating in different fields of activity, as well as to reveal the motives for implementation and benefits of implemented standards and their practical application within the side of organizations.

The research was conducted between 23 January 2021 and 30 April 2021 (see the research sequence in Figure 1). Interviews were conducted with quality representatives from organizations operating in various fields of activity: manufacturers of food, electrical equipment and plastic products, service providers, cosmetics, and pharmaceutical companies.
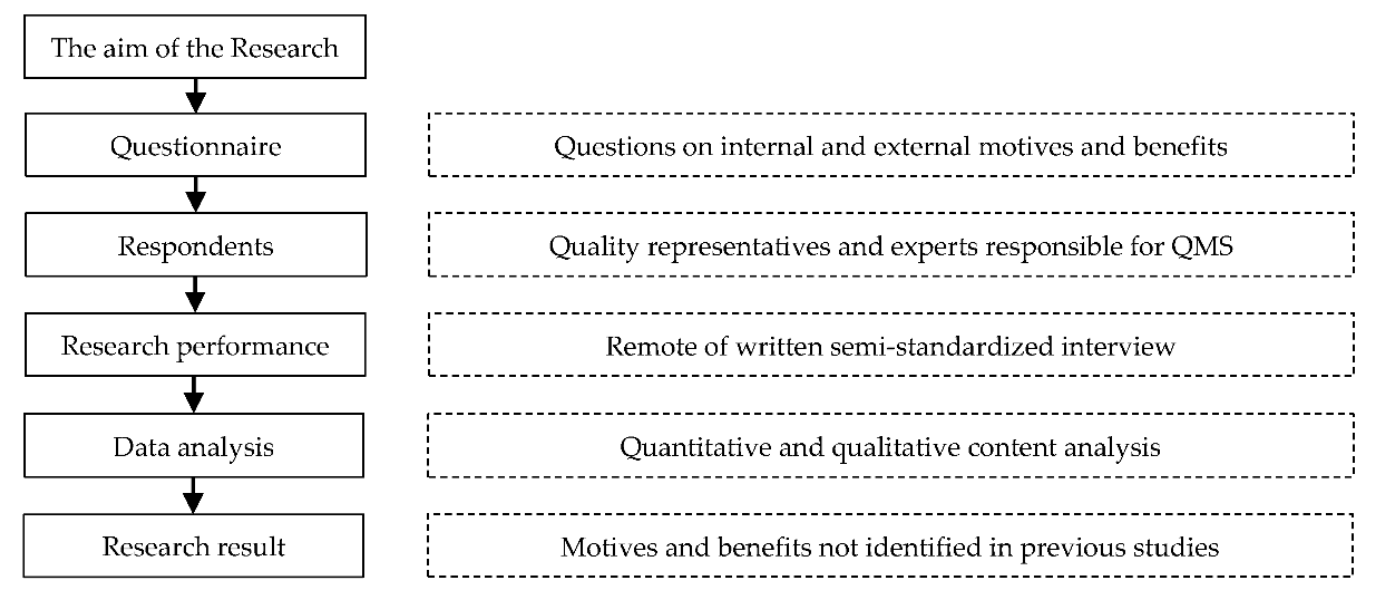

Figure 1. Research sequence.

Research limits-the research involved only organizations that are operating in Lithuania in different fields of activity and that have implemented quality management systems, with their quality representatives chosen to be the respondents.

Ten respondents were interviewed during the research (R1-R10) whose data were analyzed and summarized.

A questionnaire of the research was structured on the basis of internal motives (MI), external motives (ME), Table 1, internal benefits (BI), and external benefits (BE).

Respondents that participated in the research were quality representatives and experts who are responsible for quality management system implementation and assurance in their organizations. 
The interview was conducted remotely due to the pandemic situation in Lithuania. All respondents received the questionnaire before the interview in order to prepare properly. Half of the respondents (R1, R4, R5, R7, R8) filled the questionnaire and provided answers in writing $(\mathrm{OW})$. Remote interviews with other respondents were conducted via video communication platforms.

A quantitative as well as a thematic content analysis was applied to systematize the obtained qualitative research data.

\subsection{Characteristics of Respondents}

The research involved Lithuanian organizations with implemented quality management standards and operating in different fields of activity: manufacturing, trade, sales, services, customer service, and for-profit non-governmental organizations.

The respondents were quality representatives and experts who are directly responsible for the quality management system assurance in their organizations (Table 2).

Table 2. Qualitative research respondents from 1 to 10 , their job positions, and data collection type.

\begin{tabular}{ccc}
\hline Respondent Codes & Job Position & Data \\
\hline Respondent (R1) & Process improvement manager & OW \\
\hline Respondent (R2) & Quality director & OO \\
\hline Respondent (R3) & Process development manager & OO \\
\hline Respondent (R4) & Quality and food safety manager & OW \\
\hline Respondent (R5) & Quality manager & OW \\
\hline Respondent (R6) & Non-disclosed & OO \\
\hline Respondent (R7) & Quality manager & OW \\
\hline Respondent (R8) & Quality manager & OW \\
\hline Respondent (R9) & Quality manager & OO \\
\hline Respondent (R10) & Quality manager & OO \\
\hline
\end{tabular}

\subsection{Questionnaire Methodology for Semi-Standardized Interview Performance}

A semi-standardized interview method was chosen for the research. The elements of the questionnaire were compiled by the authors on the basis of the generalized list of motives and benefits provided by Vyšniauskienè L. [3] and Ruzevicius J. [5]. Tables 3 and 4 provide a list of questions that were used for the research and evaluated, if motives and benefits from the list in Tables 3 and 4 existed in organizations, or not. 
Table 3. Elements of the questionnaire compiled to evaluate QMS implementation motives.

\begin{tabular}{|c|c|c|}
\hline Elements of the Questionnaire (Work Author) & Motives [3] & Type \\
\hline 4.a. What were the reasons for implementing the standard? & Decision of the highest authority & MI \\
\hline \multirow[t]{17}{*}{ 4.b. External factors or internal demand? } & Maintaining and/or increasing of the market share & ME \\
\hline & Demand and/or pressure of customers & ME \\
\hline & Condition to compete in the sector & ME \\
\hline & Competitive advantage & ME \\
\hline & Improvement of quality of products and/or services & MI \\
\hline & Improvement of processes and procedures & MI \\
\hline & Reduction in incidents, rejections, and complaints & MI \\
\hline & Used as a basis for reducing internal costs & MI \\
\hline & Improvement in communication in the organization & MI \\
\hline & Improvement in management-employee relations & MI \\
\hline & Used as a promotional and/or marketing tool & ME \\
\hline & Competitive advantage & ME \\
\hline & Our competitors who have implemented ISO 9000 standards & ME \\
\hline & Direct way to a new market & ME \\
\hline & To be a good example for suppliers & ME \\
\hline & Improvement of public image of the organization & ME \\
\hline & At the request of the Government & ME \\
\hline
\end{tabular}

Note: MI-internal motives, ME-external motives

Table 4. Elements of the questionnaire compiled to evaluate existence of implemented QMS benefits in organizations.

\begin{tabular}{ccc}
\hline Elements of the Questionnaire (Work Author) & Benefits [3] & Type \\
\hline 6.a. Habits and employee culture have changed & Employees have a better understanding of quality \\
\hline 6.b. Has the investment paid off? & & \\
\hline 7.a. Are the processes written? & & Better working environment \\
\hline 7.b. How widely are the processes communicated? & Elimination of excess work \\
\hline 7.c. Is there evident employee involvement? & & BI \\
\hline 8. How do you ensure compliance with processes? & BI \\
\hline 8.a. Are employees familiarized with the processes? & Improved processes and procedures \\
\hline 10.a. How did the implemented standards affect the organization? & & BI \\
\hline
\end{tabular}

10.b. Do you see the benefits of the implemented standards?

11. How do you measure the level of the quality system?

12.a. Has the quality of services improved?

\begin{tabular}{cc} 
Improved quality of products and/or services & $\mathrm{BI}$ \\
\hline Better customer service & $\mathrm{BI}$ \\
\hline Increased customer satisfaction & $\mathrm{BE}$ \\
\hline Improved quality of suppliers & $\mathrm{BE}$ \\
\hline
\end{tabular}


Table 4. Cont.

\begin{tabular}{|c|c|c|}
\hline Elements of the Questionnaire (Work Author) & Benefits [3] & Type \\
\hline 12.b. Has the level of product defects decreased? & Decreased internal costs & $\mathrm{BI}$ \\
\hline $\begin{array}{l}\text { 12.c. Has the number of non-compliances and complaints } \\
\text { decreased? }\end{array}$ & Decreased number of incidents, rejections, and complaints & BI \\
\hline 12.d. Has employee motivation increased? & Increased workforce motivation and retention & $\mathrm{BI}$ \\
\hline 12.e. Has the company's profit increased? & Improved profitability & $\mathrm{BI}$ \\
\hline \multirow[t]{2}{*}{ 12.f. Has the company become more attractive? } & Improved corporate image in the market & $\mathrm{BE}$ \\
\hline & Greater competitive advantage & $\mathrm{BE}$ \\
\hline \multirow[t]{2}{*}{ 12.g. Has the circle of customers increased? } & Expansion into international markets & BE \\
\hline & Improved mutual cooperation with suppliers & BE \\
\hline 12.h. Is the public beginning to trust you more? & Effective promotional and/or marketing tool & $\mathrm{BE}$ \\
\hline
\end{tabular}

The type of motives indicates if motives are internal (MI) or external (ME).

Elements of the questionnaire compiled to evaluate benefits of quality management standards existence are provided in Table 4.

Type of benefits indicates if benefits are internal (BI) or external (BE).

\section{Results}

An analysis of the research results proved that there are two main groups of QMS implementation motives-external motives (ME) and internal motives (MI).

The external implementation motives were particularly prevalent in the case of customer requirements.

Respondents stated that implementation of the standard allowed maintenance of one's position in the market, the gaining of a competitive advantage, and the ability to compete in the sector; however, only three respondents (R2, R4, and R6) stated that the emergence of the standard was the only reason why the organization decided to implement it. Six respondents (R1, R3, R5, R7, R8, and R9) stated that the emergence of the standard was determined not only by external motives but also by the desire of organizations to streamline and standardize their activities, improve their processes, and ensure process management, while one respondent (R10) pointed out that its only internal aim was to improve the quality of its services.

Data of the research were systematized and are provided in Tables 5 and 6 with such a methodology - if the answers were positive and it was suitable for all respondents, it was marked with a "+"symbol in Tables 5 and 6, but if respondents evaluated that the benefits of achieved topic were not related to implemented QMS, it was marked with a "/" symbol.

In summary, it can be stated that structure of motives for implementing quality management systems remain the same, and, in previous research, motives were internal and external. However, in terms of several organizations, it can be said that the external motive has become mandatory (R2, R5). The present research revealed that companies would simply not be able to operate without an implemented quality management standard (one of the approved GxP [9], ISO 17025 [10]). Refusal to implement such standards was not an option for them.

There were no observations during the research that would indicate that the motives for implementing standards may have stemmed from the initiative to reduce incidents, to use the standard for marketing purposes, or for the purpose of improving communication within the company between managers and employees, or of becoming a good example for suppliers. The aforesaid elements were revealed in the organization through the benefits of the QMS. 
Table 5. Motives for implementing a quality management system in the organizations of respondents.

\begin{tabular}{|c|c|c|c|c|c|c|c|c|c|c|c|}
\hline Motives & Type & R1 & $\mathbf{R 2}$ & R3 & R4 & R5 & R6 & R7 & R8 & R9 & R10 \\
\hline Demand and/or pressure of customers & $\mathrm{ME}$ & + & + & + & + & + & + & + & & & \\
\hline Competitive advantage (supply selection procedures) & $\mathrm{ME}$ & + & & & & + & & & + & & \\
\hline Improvement of public image of the organization & $\mathrm{ME}$ & & & & + & & & & & + & \\
\hline Maintaining and/or increasing the market share & ME & + & & & & & + & & & & \\
\hline Condition to compete in the sector & $\mathrm{ME}$ & & + & & & + & & & & & \\
\hline Would not operate without relevant standard & $\mathrm{ME}$ & & + & & & + & & & & & \\
\hline Direct way to a new market & ME & & & & + & & & & & & \\
\hline To use it as a promotional and/or marketing tool & $\mathrm{ME}$ & & & & & & & & & & \\
\hline Our competitors who have implemented ISO 9000 standards & $\mathrm{ME}$ & & & & & & & & & & \\
\hline To be a good example for suppliers & ME & & & & & & & & & & \\
\hline At the request of the Government & $\mathrm{ME}$ & & & & & & & & & & \\
\hline Improvement of quality of products and/or services & MI & & & & & & & + & & + & + \\
\hline Demand for standardized processes & MI & & & + & & & & & + & + & \\
\hline Decision of the highest authority & MI & & & & & + & & & & & + \\
\hline Improvement of processes and procedures & MI & & & + & & + & & & & & \\
\hline Increasing operational efficiency & MI & + & & & & + & & & & & \\
\hline Process management & MI & & & + & & & & & & & \\
\hline Reduction of incidents, rejections, and complaints & MI & & & & & & & & & & \\
\hline Improvement of communication in the organization & MI & & & & & & & & & & \\
\hline Improvement of management-employee relations & MI & & & & & & & & & & \\
\hline
\end{tabular}

Even though not all organizations measured the effectiveness of QMS in the same way, all of them indicated the same thing regarding the benefits of quality management standards after their implementation.

The research results presented in Table 6 show that the external and internal benefits remain to be the prevailing ones. According to the respondents, internal benefits (BI) were an improved quality of products and/or services, a decreased number of incidents, improved profitability, increased workforce motivation (employee involvement), increased employee competence and procedural approach, improved processes and procedures (standardized procedures), easier management of organizations, and increased efficiency. External benefits (BE) were listed by respondents as increased customer satisfaction, expansion into new markets, competitive advantage, an improved image of the organization, and an increased circle of customers.

Benefits that were not revealed during the research were increased productivity and/or efficiency (BI), decreased internal costs (BI), elimination of excess work (BI), effective promotional and/or marketing tool (BE), improved quality of suppliers (BE), and improved mutual cooperation with suppliers (BE). Although these benefits have not been revealed, we cannot claim that they do not exist, do not occur, and/or have not been achieved in the organization. The study did not dive deep into the processes. For example, determining whether there was a decrease in excess work would require a thorough investigation by accessing the organization's internal processes, checking each stage of the process, the cycle time, the operation of the process, and its effectiveness. 
Table 6. Quality management system benefits in the organizations of respondents.

\begin{tabular}{|c|c|c|c|c|c|c|c|c|c|c|c|}
\hline Benefits & Type & R1 & $\mathbf{R} 2$ & R3 & R4 & R5 & R6 & R7 & R8 & R9 & R10 \\
\hline Improved processes and procedures (standardized procedures) & $\mathrm{BI}$ & + & + & & + & & + & + & + & / & + \\
\hline Employees have better understanding/competence of quality & BI & + & & + & + & + & + & & + & + & \\
\hline Improved quality of products and/or services & BI & + & / & + & & + & & + & + & / & + \\
\hline Decreased number of incidents, defects, and complaints & $\mathrm{BI}$ & + & / & + & + & + & & & & + & + \\
\hline Improved profitability & BI & + & / & + & + & & + & + & / & + & / \\
\hline Increased workforce motivation and retention (involvement) & BI & l & + & + & + & + & / & / & / & + & \\
\hline Easier management of the company & BI & & + & & & & & & & + & \\
\hline Increased efficiency & BI & + & & & + & & & & & & \\
\hline Better working environment (working conditions) & $\mathrm{BI}$ & + & & & & & & & & & \\
\hline Better customer service & BI & & & & & & & & & & + \\
\hline Increased productivity and/or efficiency & $\mathrm{BI}$ & & & & & & & & & & \\
\hline Decreased internal costs & BI & & & & & & & & & & \\
\hline Elimination of excess work & $\mathrm{BI}$ & & & & & & & & & & \\
\hline Greater competitive advantage & $\overline{B E}$ & + & & + & + & & + & + & & + & \\
\hline Increased circle of customers & $\mathrm{BE}$ & + & & + & + & & + & + & l & + & \\
\hline Expansion into international markets & $\mathrm{BE}$ & + & & + & + & + & + & & & & \\
\hline Improved image in the market and became more attractive & $\overline{\mathrm{BE}}$ & & & + & & & + & + & + & + & l \\
\hline Increased customer satisfaction & $\mathrm{BE}$ & + & & & & & & + & & & + \\
\hline Effective promotional and/or marketing tool & $\overline{\mathrm{BE}}$ & & & & & & & & & & \\
\hline Improved quality of suppliers & $\overline{\mathrm{BE}}$ & & & & & & & & & & \\
\hline Improved mutual cooperation with suppliers & $\overline{\mathrm{BE}}$ & & & & & & & & & & \\
\hline \multicolumn{12}{|c|}{$\begin{array}{l}\text { Note: } \mathrm{BI}-\text { internal benefits, } \mathrm{BE}-\text { external benefits, }[+]-\text { positive answer, [ / ] } \\
\text { fits of achieved topic are not related to implemented QMS, R1 <...> R10-respo }\end{array}$} \\
\hline
\end{tabular}

A significantly improved quality of products/services and a decrease in the number of incidents and defects/complaints was observed in the organizations. Six out of ten of the organizations indicated that the quality of their services has improved since the introduction of QMS, and there were two organizations (R2, R9) that pointed out that this improvement was not solely related to the implementation of the standard or was only related partially. Six out of ten of the organizations indicated a reduced number of incidents, defects, and complaints within the company, and one respondent indicated that this was unrelated to the implementation of QMS.

Six out of ten of the organizations also talked about improved profitability and increased workforce motivation (employee involvement), increased employee understanding of quality, and improved processes and procedures (standardized procedures) by indicating that their company's profit increased after the implementation of the standard. However, these data were provided by respondents based on their intuition and not on actual facts, and $3 / 10$ of the organizations (R2, R8, and R10) did not think that the growth of their company was linked to the implementation of QMS. Five out of ten of the respondents indicated an increase in employee motivation and involvement in the improvement of the organization's internal systems. Four out of ten of the organizations indicated that mostly there was partial involvement, which occurs only when employees see benefits (R8) or a lack of involvement due to employee turnover among lower-level employees.

As many as $7 / 10$ of the organizations claimed that their organization had become more mature with better awareness of why it is important to have an implemented quality system, which indicates that a culture had developed within the organization. Seven out of ten of the organizations revealed that after the implementation of the standard(s), clear standardized processes and responsibilities emerged, which greatly facilitated the management of the organization's activities. One organization (R9) did not link process improvement to the implementation of a standard alone, since a food safety system was already in place, and the aim was to improve it.

Only 3/10 indicated an increase in customer satisfaction (BE) after QMS; however, these results are not sufficient to declare that customers of the remaining organizations are dissatisfied, since organizations do not conduct surveys, or the respondent did not indicate 
this during the survey. Five out of ten of the respondents indicated that opportunities to enter new markets emerged, and 6/10 of the organizations indicated an improved competitive advantage. An improved image of the organizations in the market (5/10) was observed, while two organizations (R2 and R9) stated that management in their company has become easier and efficiency has increased (R1, R4), and even 6/10 of the organizations reported an increased circle of customers.

After evaluating the research results, it can be seen that organizations implementing quality management systems based on both external and internal motives benefit in the end from the implemented quality management standard:

1. If the QMS implementation motive of an organization was customer or market requirements, the organization was able to enter new markets as the end result;

2. If the QMS implementation motive of the organization was internal: to improve the company's operations, its management and operational efficiency, the management of the company became easier in the end, with the formation of employee culture, awareness, and procedural thinking, which helps improve the organization and encourages it to move forward.

\section{Discussion}

According to Ruževičius [11], apart from "traditional" quality (ISO 9001 [12]) and environment (ISO 14001 [13]) management systems, Lithuanian companies uses systems-ISO 22000 [14] (food industry chain quality management), ISO/IEC 20000 [15] (IT service management system), good manufacturing practice (GMP) [16], Forest Stewardship Council (FSC) [17]; forest management and wood processors certification, ISO/IEC 17021:2006 [18] (requirements for bodies providing audit and certification of management systems), ISO 13485 [19] (for medical devices), SA 8000 [20] (Social accountability), ISO/TS 16949 [21], ISO/IEC 27001 [22], CMMI [23], BRC Global Standard [24], etc.

The survey revealed that the core implemented standards were ISO 9001 [12], ISO 14001 [13], and ISO 45001 [25], while the rest of the standards were specialized according to the business area, i.e., implemented based on the organization's activities: a plastic packaging manufacturer implemented BRC [24], while an electricity company implemented ISO 27001 [22] and ISO 17025 [10]. A company providing clinical research services to pharmaceutical and biotechnology companies and manufacturers of medical devices implemented ISO 13485 [19] and ISO 22716 [26], and food and egg producers implemented BRC Foods [24], IFS Food [27], ISO 22000 [14], and HALAL [28] systems (see Table 7). It can be seen that the trends in the implementation of standards remain similar; however, new systems were also introduced-ISO 22716 [26], ISO 45001 [25], IFS Foods [27], and HALAL [28].

Vyšniauskienè L. [3] found that organizations have 7 internal (MI) and 10 external (ME) motives, as well as 11 internal (BI) and 7 (seven) external (BE) benefits.

Four motives that were not identified in previous research were found during this research: (1) organizations would not operate without a standard (ME), (2) improvement of operational efficiency (MI), (3) procedural management (MI), and (4) increased demand for standardized processes (MI). Current research revealed 3 benefits: (1) easier management of the company (BI), (2) increased efficiency (BI), and (3) increased circle of customers (BE). 
Table 7. Implemented standards in organizations.

\begin{tabular}{|c|c|c|c|c|c|c|c|c|c|}
\hline R1 & $\mathbf{R} 2$ & R3 & R4 & R5 & R6 & R7 & R8 & R9 & R10 \\
\hline $\begin{array}{c}\text { ISO } 9001 \\
\text { ISO } 14001 \\
\text { BRC }\end{array}$ & $\begin{array}{c}\text { ISO } 9001 \\
\text { ISO } 13485\end{array}$ & $\begin{array}{c}\text { ISO } 9001 \\
\text { ISO } 14001 \\
\text { ISO } 45001\end{array}$ & $\begin{array}{c}\text { BRC Food } \\
\text { IFS Food } \\
\text { ISO } 14001 \\
\text { RSPO }\end{array}$ & $\begin{array}{c}\text { ISO } 9001 \\
\text { ISO } 14001 \\
\text { ISO } 45001 \\
\text { ISO } 27001 \\
\text { ISO } 17025\end{array}$ & $\begin{array}{c}\text { BRC Food } \\
\text { HALAL } \\
\text { ECO }\end{array}$ & $\begin{array}{l}\text { ISO } 22000 \\
\text { ISO } 13485 \\
\text { ISO } 22716\end{array}$ & $\begin{array}{c}\text { ISO } 9001 \\
\text { ISO } 14001 \\
\text { ISO } 45001\end{array}$ & BRC Food & ISO 9001 \\
\hline
\end{tabular}

Note: R1 <... R10—respondent

It is likely that the research did not reveal all the benefits of implementing the standard. It can be concluded that increased productivity, reduced internal costs, and elimination of excess work are the main benefits of an organization included in the empirical research; however, this was not revealed. The main reason for this is the scope of the research, since, in order to determine productivity, costs, and elimination of excess work, the research should take place continuously within the organization itself, with the possibility to access its processes.

\section{The Concept of the Model of Benefits of Standards}

When implementing a quality management system, organizations can choose one motive or another depending on their objectives set for the quality management systemwhether the motive is only external or internal or both external and internal.

The benefits of a standard can be determined when the system is not yet fully implemented. This is reflected when employees contribute to the improvement of the organization's quality system and development of its processes. This should be particularly evident when an organization implements QMS for internal rather than external motives. In addition to employee involvement, the benefits of improving processes and procedures is also revealed later on, with the appearance of clear responsibilities and easier management of an organization at the process level. This benefit can be revealed regardless of the implementation motives (either external or internal), since the standard itself obliges standardization of the system.

Summarized results of this research (see Tables 5 and 6) provided the basis for proposing the model of systematized motives and benefits of quality management standards (see Figure 2).

The benefits of quality management standards that directly contribute to the growth of the organization (improved quality of products/services, reduced number of incidents, increased circle of customers and profit of the company, etc.) were also revealed.

The research proved that not only that the same motives and benefits for implementing QMS in organizations remain, which were revealed by previous studies, but that there are other external motives, which would not operate without the relevant standard (ME), and internal motives, increasing operational efficiency (MI), process management (MI), and demand for standardized processes (MI). Additionally, other benefits, such as external benefits - increased circle of customers (BE) — and internal benefits — easier management of the company (BI) and increased efficiency (BI)—-were revealed. 


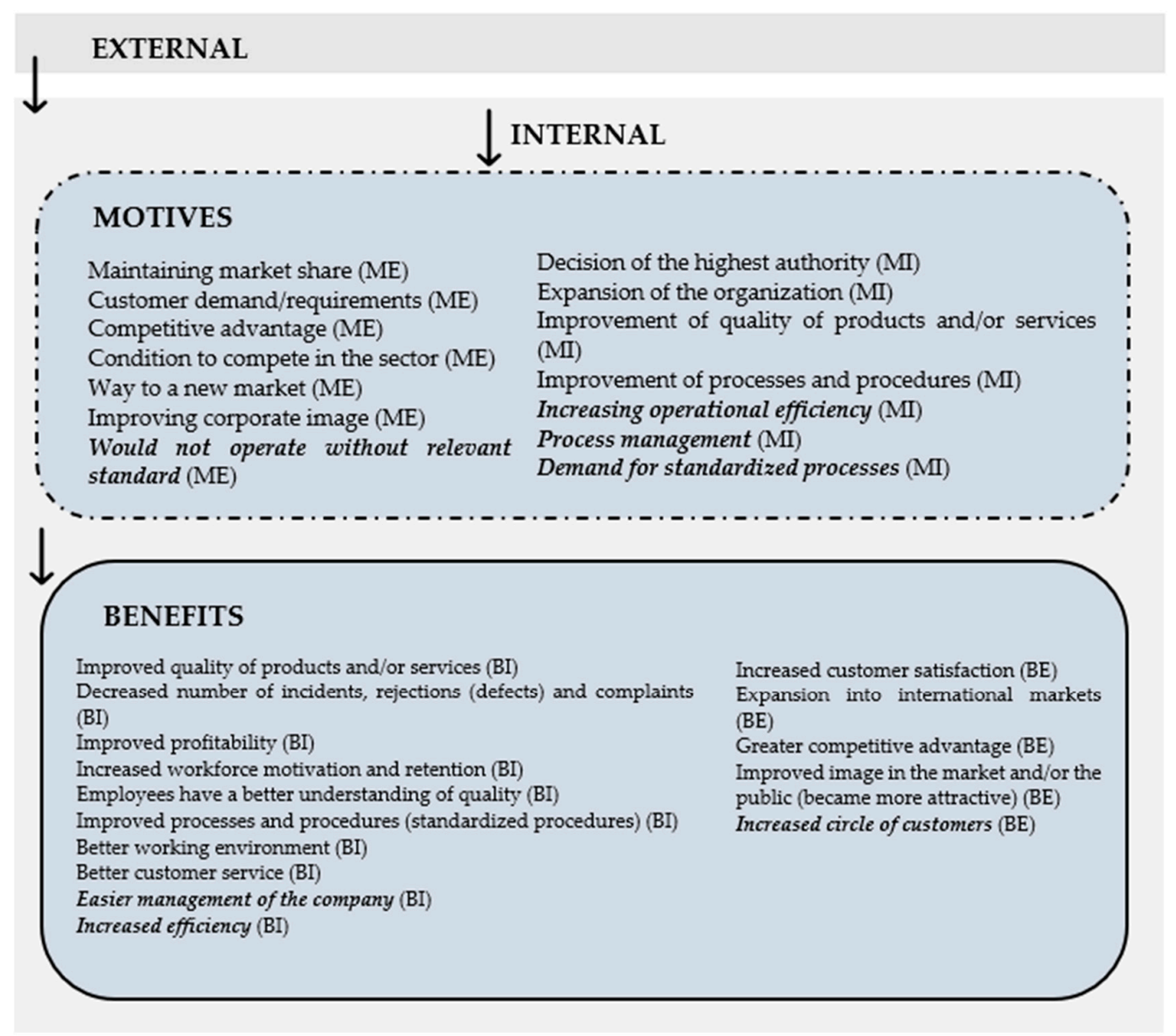

Figure 2. Model of systematized motives and benefits of quality management standards.

Organizations should monitor and evaluate whether the implemented QMS system provides the added benefits that were expected before implementation, regardless of whether the motives were internal or external:

1. If the motive of an organization to implement QMS was only external, the organization should set at least the following system monitoring indicators for the end result:

a. Improved profitability;

b. Increased circle of customers;

c. Increased customer satisfaction.

2. If the motive of an organization to implement QMS was internal (improvement of the company's activities and its management and operational efficiency), it should set indicators allowing the organization to determine the involvement of its employees and operational efficiency. Various qualitative indicators could be determined, such as:

a. Process quality level indicator;

b. Complaint and defect reduction indicator;

c. Proposal system for process improvement;

d. Customer surveys, etc.

If an organization has implemented quality management standards for external reasons, and if it achieves its set result (increased circle of customers, expanded market share, increased profit of company), it should consider changing its motives to internal ones, and aim to not only meet customer demand/requirements but also to improve the company's internal system and employee involvement.

Organizations should establish clear key performance indicators' (KPI) process monitoring and evaluate their system to see if the implemented quality management system provides the added value that they expected before the QMS implementation, and accredi- 
tation companies should take this more into account in certification or annual follow-up audits and make sure that the organization monitors these indicators.

\section{Conclusions}

1. Organizations implementing quality management systems based on both external and internal motives benefit from the implemented standards at the end. If the motive for the implementation of an organization's QMS is customer or market requirements, such an organization is able to enter new markets in the end. If the motive is internal (improvement of the company's activities and its management and operational efficiency), the management of the company becomes easier in the end with improvements in employee culture, awareness, and procedural thinking, which help further develop the organization.

2. The data of the empirical research indicate that, after the implementation of QMS, the level of quality improved, the number of incidents and defects (complaints) decreased, and employee involvement and understanding of quality increased. More than half of the respondents indicated an increase in their company's profits, increased customer satisfaction, easier management of the company, and increased efficiency; however, results such as data on the company's profits were provided by respondents based on their intuition instead of actual facts. A conclusion can be drawn that organizations see the implemented quality management standards as beneficial; however, these data are not based solely on the internal indicators of companies.

3. The authors suggest such a possible standardization and quality management development insights for future research: (a) the evaluation of real and comparable values of management systems' certificates, delivered by different conformity assessment institutions; (b) the evaluation of the efficiency and influence of standardization, QMSs, environmental management systems, and eco-labelling tools on a company's added value and a country's gross domestic product.

4. The interviews were conducted with quality representatives/ experts but not with operational level employees, and the research was conducted with a small amount of organizations based in Lithuania. Future research should be performed with organizations in foreign countries and interviewed with operational-level employees.

Author Contributions: Conceptualization, A.Z. and J.R.; methodology, D.R.; validation, J.R. and D.R.; investigation, A.Z.; writing-original draft preparation, A.Z.; writing-review and editing, D.R.; visualization, A.Z.; supervision, D.R.; project administration, J.R. All authors have read and agreed to the published version of the manuscript.

Funding: This research received no external funding.

Institutional Review Board Statement: Not applicable.

Informed Consent Statement: Not applicable.

Data Availability Statement: Publicly available master thesis data were analyzed in this study. Master thesis can be found here: http:/ / www.kv.ef.vu.lt/wp-content/uploads/2021/06/Ar\%C5 \%ABnas-Zgirskas-MBD.pdf (accessed on 27 August 2021).

Conflicts of Interest: The authors declare no conflict of interest.

\section{References}

1. Ruževičius, J. Quality Management Models and Their Application to Improve the Performance of Organizations; Vilnius University: Vilnius, Lithuania, 2006.

2. Poksinska, B.; Dahlgaard, J.J.; Antoni, M. The state of ISO 9000 certification: A study of Swedish organizations. TQM Mag. 2002, 14, 297-306. [CrossRef]

3. Vyšniauskienė, L. The Motives and Benefits of Implementing Quality Management Systems in Lithuanian Organizations. Sci. J. Manag. Theory Stud. Rural Bus. Infrastruct. Dev. 2014, 36, 167-176. 
4. Echour, S.; Nbigui, T. Motivations related to the quality management system and benefits of its implementation in the company: State of the art. In Proceedings of the13th International Colloquium of Logistics and Supply Chain Management (LOGISTIQUA), Sidi Mohamed Ben Abdellah University, Fez, Morocco, 2-4 December 2020.

5. Ruževičius, J. Standardisation et Réglamentation de la Qualité. In Management de la Qualité. Notion Globale et Recherche en la Matière; Maison d'éditions: Vilnius, Lithuania, 2012; pp. 137-175.

6. Gotzamani, K.D.; Tsiotras, G.D. The true motives behind ISO 9000 certification-their effect on the overall certification benefits and long term contribution towards TQM. Int. J. Qual. Reliab. Manag. 2001, 19, 151-169. [CrossRef]

7. Gremyr, I.; Lenning, J.; Elg, M.; Martin, J. Increasing the value of quality management systems. Int. J. Qual. Serv. Sci. 2021, 13, 381-394.

8. Rusjan, B.; Alič, M. Capitalising on ISO 9001 benefits for strategic results. Int. J. Qual. Reliab. Manag. 2010, 27, 756-778. [CrossRef]

9. Cognidox. GxP Compliance Guide. Available online: https://www.cognidox.com/the-guide-to-gxp-compliance (accessed on 20 September 2021).

10. ISO/IEC 17025. Testing and Calibration Laboratories. International Organization for Standardization. Available online: https:/ / www.iso.org/ISO-IEC-17025-testing-and-calibration-laboratories.html (accessed on 20 September 2021).

11. Ruževičius, J. The Study of Quality Certification System of Lithuania. Eng. Econ. 2008, 57, 78-84.

12. ISO 9001:2015. Quality Management Systems—Requirements. International Organization for Standardization. Available online: https: / / www.iso.org/standard/62085.html (accessed on 20 September 2021).

13. ISO 14001:2015. Environmental Management Systems-Requirements for Guidance to Use. International Organization for Standardization. Available online: https:/ / www.iso.org/standard/60857.html (accessed on 20 September 2021).

14. ISO 22000. Food Safety Management. International Organization for Standardization. Available online: https://www.iso.org/ iso-22000-food-safety-management.html (accessed on 20 September 2021).

15. ISO/IEC 20000-1:2018. Information Technology—Service Management-Part 1: Service Management System Requirements. International Organization for Standardization. Available online: https://www.iso.org/standard/70636.html (accessed on 20 September 2021).

16. Good Manufacturing Practice (GMP). European Medicines Agency. Available online: https://www.ema.europa.eu/en/humanregulatory/research-development/compliance/good-manufacturing-practice (accessed on 20 September 2021).

17. Forest Stewardship Council (FRC). Available online: https:/ / fsc.org/en (accessed on 20 September 2021).

18. ISO/IEC 17021:2006. Conformity Assessment-Requirements for Bodies Providing Audit and Certification of Management Systems. International Organization for Standardization. Available online: https:/ / www.iso.org/standard/29343.html (accessed on 20 September 2021).

19. ISO 13485:2016. Medical Devices-Quality Management Systems-Requirements for Regulatory Purposes. International Organization for Standardization. Available online: https://www.iso.org/standard/59752.html (accessed on 20 September 2021).

20. SA 8000 Standard. Social Accountability International (SAI). Available online: https://sa-intl.org/programs/sa8000/ (accessed on 20 September 2021).

21. ISO/TS 16949. Quality Management Systems—Particular Requirements for the Application of ISO 9001:2008 for Automotive Production and Relevant Service Part Organizations. International Organization for Standardization. Available online: https: //www.iso.org/standard/52844.html (accessed on 20 September 2021).

22. ISO/IEC 27001. Information Security Management. International Organization for Standardization. Available online: https: //www.iso.org/isoiec-27001-information-security.html (accessed on 20 September 2021).

23. White, K.S. What Is CMMI? A Model for Optimizing Development Processes / / CIO. Available online: https://www.cio.com/ article/2437864/process-improvement-capability-maturity-model-integration-cmmi-definition-and-solutions.html (accessed on 20 September 2021).

24. BRCGS Global Food Safety Standard. Available online: https://www.brcgs.com/our-standards/food-safety/ (accessed on 20 September 2021).

25. ISO 45001:2018. Occupational Health and Safety Management Systems-Requirements with Guidance for Use. International Organization for Standardization. Available online: https:/ / www.iso.org/standard/63787.html (accessed on 20 September 2021).

26. ISO 22716:2007. Cosmetics_Good Manufacturing Practices (GMP)—Guidelines on Good Manufacturing Practices. International Organization for Standardization. Available online: https://www.iso.org/standard/36437.html (accessed on 20 September 2021).

27. IFS Food 7. International Featured Standards. Available online: https://www.ifs-certification.com/index.php/en/standards/41 28-ifs-food-standard-en (accessed on 20 September 2021).

28. HALA. A Guide for Non-Muslims. Islamic Council for Viktoria (ICV). Available online: https://www.icv.org.au/about/aboutislam-overview/what-is-halal-a-guide-for-non-muslims / (accessed on 20 September 2021). 